\title{
ChemComm
}

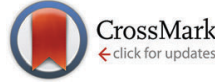

Cite this: Chem. Commun., 2014, 50, 11385

Received 22nd July 2014,

Accepted 31st July 2014

DOI: $10.1039 / c 4 c c 05666 c$

www.rsc.org/chemcomm

\section{Bronze, silver and gold: functionalized group 11 organotin sulfide clusters $\dagger$}

\author{
Jens P. Eußner and Stefanie Dehnen*
}

The synthesis, properties and reactivity of group 11 organotin sulfide clusters $\left[\left(\mathrm{R}^{1} \mathrm{Sn}\right)_{4}(\mathrm{SnCl})_{2}\left(\mathrm{MPPh}_{3}\right)_{2} \mathrm{~S}_{8}\right](\mathrm{M}=\mathrm{Cu}, \mathrm{Ag}),\left[\left(\mathrm{R}^{3} \mathrm{Sn}\right)_{10} \mathrm{Ag}_{10} \mathrm{~S}_{20}\right]$, and $\left[\left(\mathrm{R}^{1,3} \mathrm{Sn}\right)_{2}(\mathrm{AuPPh})_{2} \mathrm{~S}_{4}\right]$ with covalently bound, carbonyl or hydrazineterminated ligands $\mathrm{R}^{1}=\mathrm{CMe}_{2} \mathrm{CH}_{2} \mathrm{C}(\mathrm{Me}) \mathrm{O}$ or $\mathrm{R}^{3}=\mathrm{CMe}_{2} \mathrm{CH}_{2} \mathrm{C}(\mathrm{Me}) \mathrm{NNH}_{2}$ are reported.

The last few decades have afforded a large variety of ligandprotected chalcogenide clusters of group 11 metals. ${ }^{1}$ Ternary complexes and clusters were also reported, ${ }^{2}$ which often combined structural and physical properties of the binary components. ${ }^{3}$ Additionally, with regard to further reactivity, the introduction of functionalized phosphines was achieved. ${ }^{4}$ Consequently, the combination of functional organic ligand shells with finely tunable (ternary or multinary) inorganic cores, providing even more diversity, is thus of interest for diverse purposes, such as for optoelectronics or solar cell development. ${ }^{5}$ To address suitable functional materials, the synthesis and directed derivatization of clusters with covalently attached organic groups have currently been investigated in detail for polyoxometalates ${ }^{6}$ as well as for group 14/16 compounds, ${ }^{7}$ for instance.

The organic groups on the periphery of organogermanium and organotin sulfide complexes of the general type $\left[\left(\mathrm{R}^{\mathrm{f}} \mathrm{T}\right)_{x} \mathrm{~S}_{y}\right]$ $\left(\mathrm{R}^{\mathrm{f}}=\right.$ functionalized organic ligand: $\mathrm{R}^{1}=\mathrm{CMe}_{2} \mathrm{CH}_{2} \mathrm{C}(\mathrm{Me}) \mathrm{O}, \mathrm{HR}^{2}=$ $\mathrm{C}_{2} \mathrm{H}_{4} \mathrm{COOH} ; \mathrm{T}=\mathrm{Ge}, \mathrm{Sn} ; x / y=4 / 6,6 / 10$ ) are reactive towards hydrazine derivatives, which allowed further derivatizations of the organic ligand shell. ${ }^{8}$ Hereby, an extension of the ligand shell towards ligands such as $\mathrm{R}^{3}=\mathrm{CMe}_{2} \mathrm{CH}_{2} \mathrm{C}(\mathrm{Me}) \mathrm{NNH}_{2}, \mathrm{R}^{4}=$ $\left\{\mathrm{CMe}_{2} \mathrm{CH}_{2} \mathrm{C}(\mathrm{Me}) \mathrm{NNH}\right\}_{2} \mathrm{CO}$, or $\mathrm{R}^{5}=\mathrm{CMe}_{2} \mathrm{CH}_{2} \mathrm{C}(\mathrm{Me}) \mathrm{NNC}(2-\mathrm{py})_{2}$ was achieved. Reactions with transition metal compounds additionally enabled the extension of the inorganic core to form the

Philipps-Universität Marburg, Fachbereich Chemie and Wissenschaftliches Zentrum für Materialwissenschaften (WZMW), Hans-Meerwein-Straße, D-35043 Marburg, Germany. E-mail: dehnen@chemie-uni-marburg.de; Fax: +49 6421 2825653; Tel: +4964212825751

$\dagger$ Electronic supplementary information (ESI) available: Further details of syntheses, analyses, and crystallographic data/further figures for 1-6 and $\left(\mathrm{Me}_{3} \mathrm{Si}\right)_{2} \mathrm{~S}$. CCDC 1011096-1011102. For ESI and crystallographic data in CIF or other electronic format see DOI: $10.1039 / \mathrm{c} 4 \mathrm{cc} 05666 \mathrm{c}$ organofunctionalized ternary clusters $\left[\left(\mathrm{R}^{3} \mathrm{~T}\right)_{2}\left(\mathrm{CuPR}_{3}\right)_{6} \mathrm{~S}_{6}\right],{ }^{8}$ $\left[\left(\mathrm{R}^{2} \mathrm{Sn}\right)_{6}(\mathrm{OMe})_{6} \mathrm{Cu}_{2} \mathrm{~S}_{6}\right]^{4-,},{ }^{8}\left[\left(\mathrm{R}^{3} \mathrm{Ge}\right)_{4} \mathrm{Pd}_{6} \mathrm{~S}_{12}\right]^{9}$ and $\left[\mathrm{R}_{2}^{4}\left\{\mathrm{Sn}(\mu-\mathrm{S})_{2^{-}}\right.\right.$ $\left.\left.\mathrm{Cu}\left(\mathrm{PPh}_{2} \mathrm{Me}\right)\right\}_{4}\right]^{10}{ }^{10}$ Bispyridine-decorated clusters $\left[\left(\mathrm{R}^{5} \mathrm{Sn}\right)_{4}(\mathrm{ZnX})_{4} \mathrm{~S}_{8}\right]$ $(\mathrm{X}=\mathrm{Cl}, \mathrm{Br}, \mathrm{I})$ were obtained by slow diffusion of zinc halide solutions into solutions of the organotin sulfide cluster $\left[\left(\mathrm{R}^{5} \mathrm{~T}\right)_{6} \mathrm{~S}_{10}\right] \cdot{ }^{11}$

Further structurally characterized ternary group 11 metal/ organotin sulfide clusters have so far been surrounded by unreactive organic groups, as in $\left[(\mathrm{PhSn})_{2}\left(\mathrm{CuPPh}_{2} \mathrm{Me}\right)_{6} \mathrm{~S}_{6}\right]{ }^{12}$ $\left[(\mathrm{PhSn})_{12} \mathrm{Cu}_{19}\left(\mathrm{PEt}_{2} \mathrm{Ph}\right)_{3} \mathrm{~S}_{28}\right]^{+},{ }^{13}$ and the mixed-valence compound $\left[\left\{\left(\mathrm{CH}_{2}\right)_{4} \mathrm{Sn}^{\mathrm{IV}}\right\}_{6}\left(\mathrm{CuPPh}_{3}\right)_{6} \mathrm{Sn}^{\mathrm{II}} \mathrm{Cu}_{4} \mathrm{~S}_{12}\right]{ }^{14}$ Ternary complexes containing $\mathrm{Ag} / \mathrm{Sn} / \mathrm{S}$ or $\mathrm{Au} / \mathrm{Sn} / \mathrm{S}$ cores have not been characterized yet using X-ray diffraction.\$

Recently we reported new functional organotin sulfide complexes of the type $\left[\left(\mathrm{R}^{1,3} \mathrm{Sn}\right)_{3} \mathrm{~S}_{4} \mathrm{Cl}\right]$ that exhibit defect heterocubane scaffolds with carbonyl and hydrazone groups. ${ }^{15}$ Herein, we show that these turned out to be suitable precursor complexes as well. $\left[\left(\mathrm{R}^{1} \mathrm{Sn}\right)_{3} \mathrm{~S}_{4} \mathrm{Cl}\right]$ (A) reacts with the group 11 metal complexes $\left[\mathrm{Cu}\left(\mathrm{PPh}_{3}\right)_{3} \mathrm{Cl}\right],\left[\mathrm{Ag}\left(\mathrm{PPh}_{3}\right)_{3} \mathrm{Cl}\right]$ and $\left[\mathrm{Au}\left(\mathrm{PPh}_{3}\right) \mathrm{Cl}\right]$ in $\mathrm{CH}_{2} \mathrm{Cl}_{2}$ with $\left(\mathrm{Me}_{3} \mathrm{Si}\right)_{2} \mathrm{~S}$, in the case of $\mathrm{Ag}$ and $\mathrm{Au}$ complexes with subsequent in situ derivatization by hydrazine hydrate (Scheme 1), to yield single crystals of the following compounds comprising ternary clusters $\left[\left(\mathrm{R}^{1} \mathrm{Sn}\right)_{4}(\mathrm{SnCl})_{2}\left(\mathrm{CuPPh}_{3}\right)_{2} \mathrm{~S}_{8}\right] \cdot 4 \mathrm{CH}_{2} \mathrm{Cl}_{2}$ $\left(\mathbf{1} \cdot 4 \mathrm{CH}_{2} \mathrm{Cl}_{2}\right), \mathbf{1} \cdot\left[\left(\mathrm{R}^{1} \mathrm{Snn}\right)_{4} \mathrm{~S}_{6}\right]$ (hereafter denoted as 2), $\left[\left(\mathrm{R}^{1} \mathrm{Sn}\right)_{4}(\mathrm{SnCl})_{2^{-}}\right.$ $\left.\left(\mathrm{CuPPh}_{3}\right)_{2} \mathrm{~S}_{8}\right] \cdot\left[\left(\mathrm{R}^{1} \mathrm{Sn}\right)_{4} \mathrm{~S}_{6}\right]\left(3 \cdot\left[\left(\mathrm{R}^{1} \mathrm{Sn}\right)_{4} \mathrm{~S}_{6}\right]\right),\left[\left(\mathrm{R}^{3} \mathrm{Sn}\right)_{10} \mathrm{Ag}_{10} \mathrm{~S}_{20}\right] \cdot 3.5 \mathrm{CH}_{2} \mathrm{Cl}_{2}$ $\left(4 \cdot 3.5 \mathrm{CH}_{2} \mathrm{Cl}_{2}\right),\left[\left\{\mathrm{R}^{1} \mathrm{Sn}(\mu-\mathrm{S})\right\}_{2}\left\{\mathrm{AuPPh}_{3}(\mu-\mathrm{S})\right\}_{2}\right](5)$, and $\left[\left\{\mathrm{R}^{3} \mathrm{Sn}(\mu-\mathrm{S})\right\}_{2}{ }^{-}\right.$ $\left.\left\{\operatorname{AuPPh}_{3}(\mu-S)\right\}_{2}\right] \cdot 5 \mathrm{CH}_{2} \mathrm{Cl}_{2} \quad\left(6 \cdot 5 \mathrm{CH}_{2} \mathrm{Cl}_{2}\right)$. The clusters exhibit

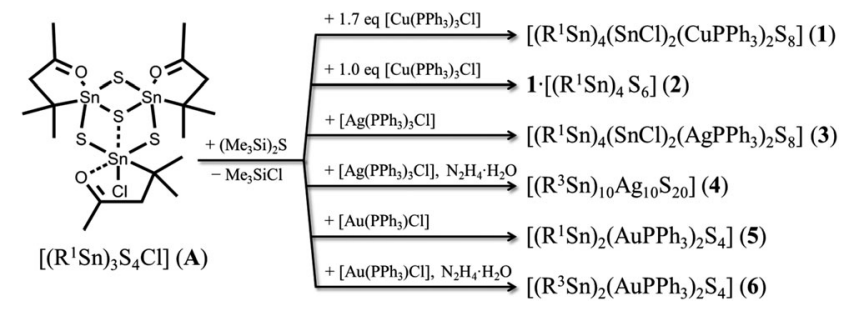

Scheme 1 Synthesis of compounds 1-6 $\left(\mathrm{R}^{1}=\mathrm{CMe}_{2} \mathrm{CH}_{2} \mathrm{C}(\mathrm{Me}) \mathrm{O}\right.$, $\left.\mathrm{R}^{3}=\mathrm{CMe}_{2} \mathrm{CH}_{2} \mathrm{C}(\mathrm{Me}) \mathrm{NNH}_{2}\right)$. 


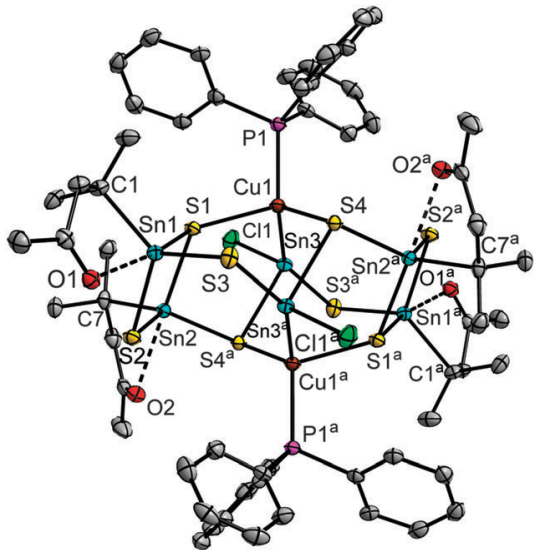

Fig. 1 Molecular structure of 1 without $\mathrm{H}$ atoms (ellipsoids drawn at $50 \%$ probability); $a=1-x,-y,-z$. Selected structural parameter $\left[\AA \AA{ }^{\circ}\right]$ : Sn-S 2.3654(8)-2.5058(8), Sn(1,2)-C 2.183(3)-2.192(3), Sn(1,2) ..O(1,2) 2.516(2)2.537(2), Sn3-Cl1 2.4713(8), Sn3-Cu1 2.6054(4), Cu1-S(1,4) 2.3626(9)2.3166(8), Cu1-P1 2.2590(8); Sn-S-Sn 86.57(2)-89.70(3), S-Sn-S 91.24(3)-121.81(3), Cu1-Sn3-S3 ${ }^{\mathrm{a}}$ 149.75(2), Cu1-Sn3-S4 ${ }^{\mathrm{a}}$ 107.60(2), Cl1-Sn3-Cu1 111.23(2), Cl1-Sn3-S3 90.20(3), Cl1-Sn3-S4a 95.70(3), C-Sn-O 72.10(10)-73.71(10).

different topologies and compositions and comprise reactive substituents with either carbonyl or hydrazone groups. In addition, we report the single crystal X-ray diffraction analysis of $\left(\mathrm{Me}_{3} \mathrm{Si}\right)_{2} \mathrm{~S}$ (see $\left.\mathrm{ESI} \dagger\right)$.

The reaction of $\mathbf{A}$ with $1.7 \mathrm{eq}$. $\left[\mathrm{Cu}\left(\mathrm{PPh}_{3}\right)_{3} \mathrm{Cl}\right]$ and $\left(\mathrm{Me}_{3} \mathrm{Si}\right)_{2} \mathrm{~S}$ in $\mathrm{CH}_{2} \mathrm{Cl}_{2}$, and subsequent layering with $n$-hexane yielded $\left[\left(\mathrm{R}^{1} \mathrm{Sn}\right)_{4}(\mathrm{SnCl})_{2}\left(\mathrm{CuPPh}_{3}\right)_{2} \mathrm{~S}_{8}\right] \cdot 4 \mathrm{CH}_{2} \mathrm{Cl}_{2}\left(\mathbf{1} \cdot 4 \mathrm{CH}_{2} \mathrm{Cl}_{2}\right)$ as light yellow crystals. In the molecular structure of the cluster, two $\left\{\mathrm{R}^{1} \mathrm{Sn}(\mu-\mathrm{S})\right.$ $\left.\left(\mu_{3}-\mathrm{S}\right)\right\}_{2}$ moieties are linked by two $\left\{\left(\mathrm{CuPPh}_{3}\right)(\mathrm{SnCl})\right\}$ units (see Fig. 1). The $\mathrm{R}^{1} \mathrm{Sn}$ atoms $\mathrm{Sn} 1$ and $\mathrm{Sn} 2$ show a trigonal bipyramidal coordination environment, with the axial positions being occupied by $\mathrm{O} 1, \mathrm{O} 2$ and $\mathrm{S} 1$, whereas $\mathrm{S} 2, \mathrm{~S} 3$ and $\mathrm{C} 1$ (Sn1) or S2, S4 and $\mathrm{C} 7(\mathrm{Sn} 2)$ are situated in the equatorial positions. The $\mu_{3}-\mathrm{S}-$ bridging atoms $\mathrm{S} 1$ and $\mathrm{S} 4$, and the $\mu$-bridging atom $\mathrm{S} 3$ connect the $\left\{\mathrm{R}^{1} \operatorname{Sn}(\mu-S)\left(\mu_{3}-S\right)\right\}$ moieties to the central part of the cluster. Here, $\mathrm{Cu} 1$ is surrounded in a tetrahedral fashion by a $\mathrm{PPh}_{3}$ ligand, $\mathrm{S} 1, \mathrm{~S} 4$ and Sn3. The latter has a formal oxidation state of $+_{\mathrm{II}}$ and exhibits a distorted pseudo-trigonal bipyramidal environment, with $\mathrm{Cu} 1$ and $\mathrm{S}^{\mathrm{a}}{ }^{\mathrm{a}}$ in the "axial" positions (Cu1-Sn3-S3 ${ }^{\mathrm{a}}$ $\left.149.75(2)^{\circ}\right)$, and $\mathrm{Cl} 1, \mathrm{~S}^{\mathrm{a}}$ and the sterically active lone pair in the "equatorial" positions; further pseudo-trigonal bipyramidal coordination geometries of $\mathrm{Sn}^{\mathrm{II}}$ atoms have been described by Jurkschat and co-workers. ${ }^{16}$ The mixed-valence situation in $\mathbf{1}$ was confirmed using DFT calculations (see below). As another peculiarity, 1 comprises a rare $\mathrm{Cu}-\mathrm{Sn}$ bond (Cu1-Sn3 2.6054(4) Å), which was formed in situ. ${ }^{17}$ It is not possible to monitor the formation process in detail due to the fairly complex reaction mixture and due to the poor solubility of the product. However, we assume that the reduction of $\mathrm{RSn}^{\mathrm{IV}}$ to $\mathrm{Sn}^{\mathrm{II}}$ comes along with the oxidation of the released organic ligand as discussed for the mixed valence compounds $\left[\left(\mathrm{R}^{1,3} \mathrm{Sn}\right)_{3} \mathrm{Se}_{4}\right]\left[\mathrm{SnCl}_{3}\right]$ under similar reaction conditions; ${ }^{15}$ the oxidation of $\mathrm{PPh}_{3}$ or $\mathrm{Cu}^{\mathrm{I}}$, however, was not observed under the reaction conditions, which was clarified using NMR studies and test for $\mathrm{Cu}^{2+}$ with $\mathrm{NH}_{3}$.
The observation of formal $\mathrm{Sn}^{\mathrm{II}}$ and $\mathrm{Sn}^{\mathrm{IV}}$ atoms is in agreement with natural charges, obtained by natural population analyses (NPA $)^{18}$ of the DFT wave function, which was calculated by simultaneous optimization of the geometric and electronic structure using the program system TURBOMOLE. ${ }^{19}$ The formal $\mathrm{Sn}^{\mathrm{IV}}$ atoms exhibit charges of +1.38 and +1.47 , which are larger than the +0.88 charge calculated for the formal $\mathrm{Sn}^{\mathrm{II}}$ atoms by a factor of 1.6 to 1.7 . Details of the DFT calculations are provided in the ESI. $\dagger$

Neither variation of the stoichiometry of the starting materials nor attempts to replace the $\mathrm{Cl}^{-}$ligand have led to the isolation of further clusters until now. An analogous reaction with $1.0 \mathrm{eq}$. $\left[\mathrm{Cu}\left(\mathrm{PPh}_{3}\right)_{3} \mathrm{Cl}\right]$, however, yielded $\mathbf{1} \cdot\left[\left(\mathrm{R}^{1} \mathrm{Sn}\right)_{4} \mathrm{~S}_{6}\right](2)$. The structural parameters of the two large co-crystallizing clusters in $\mathbf{2}$ are similar to those observed in $\mathbf{1} \cdot 4 \mathrm{CH}_{2} \mathrm{Cl}_{2}$ (see $\mathrm{ESI} \dagger$ ) and $\left[\left(\mathrm{R}^{1} \mathrm{Sn}\right)_{4} \mathrm{~S}_{6}\right] \cdot{ }^{20}$

Upon reaction with $\left[\mathrm{Ag}\left(\mathrm{PPh}_{3}\right)_{3} \mathrm{Cl}\right]$ and $\left(\mathrm{Me}_{3} \mathrm{Si}\right)_{2} \mathrm{~S}$ at $-78{ }^{\circ} \mathrm{C}$ in $\mathrm{CH}_{2} \mathrm{Cl}_{2}$, and subsequent, careful warming-up to room temperature, a colorless precipitate was obtained, which was re-dissolved by addition of excess of $\mathrm{CH}_{2} \mathrm{Cl}_{2}$. Layering with $n$-hexane afforded $\left[\left(\mathrm{R}^{1} \mathrm{Sn}\right)_{4}(\mathrm{SnCl})_{2}(\mathrm{AgPPh})_{2} \mathrm{~S}_{8}\right] \cdot\left[\left(\mathrm{R}^{1} \mathrm{Sn}\right)_{4} \mathrm{~S}_{6}\right]\left(3 \cdot\left[\left(\mathrm{R}^{1} \mathrm{Sn}\right)_{4} \mathrm{~S}_{6}\right]\right)$ as light yellow crystals. The ternary cluster is isostructural to that in 2 , hence the structural parameters are similar to those observed in $\mathbf{1}$ or $\mathbf{2}$, except the expected elongation of $\mathrm{M}-\mathrm{S}, \mathrm{M}-\mathrm{P}$ and $\mathrm{M}-\mathrm{Sn}$ bonds (Ag1-Sn3 2.6803(3) $\AA$ ) for $\mathrm{M}=\mathrm{Ag}$ in comparison with $\mathrm{M}=\mathrm{Cu}$, and a larger Sn-M-P angle (1: 115.40(3) for $\mathrm{M}=\mathrm{Cu}, 3$ : 131.23(2) for $\mathrm{M}=\mathrm{Ag})$. For the selected structural parameters and NPA results see the ESI. $\dagger$

Addition of hydrazine hydrate to the re-dissolved solution, and subsequent layering with $n$-hexane produced orange crystals of the hydrazone functionalized cluster $\left[\left(\mathrm{R}^{3} \mathrm{Sn}\right)_{10} \mathrm{Ag}_{10} \mathrm{~S}_{20}\right]$. $3.5 \mathrm{CH}_{2} \mathrm{Cl}_{2}\left(4 \cdot 3.5 \mathrm{CH}_{2} \mathrm{Cl}_{2}\right) .4$ consists of three $\left\{\mathrm{R}^{3} \mathrm{Sn}(\mu-\mathrm{S})\left(\mu_{3}-\mathrm{S}\right)\right\}_{2}$ units and two $\left\{\left[\mathrm{R}^{3} \mathrm{Sn}(\mu-\mathrm{S})\right]_{2}\left(\mu_{3}-\mathrm{S}\right)\left(\mu_{4}-\mathrm{S}\right)\right\}$ moieties that are linked by ten $\mathrm{Ag}$ atoms (see Fig. 2). All Sn atoms exhibit trigonal bipyramidal coordination, with $\mathrm{N}$ and $\mathrm{S}$ atoms in the axial positions. Four Ag atoms (Ag1, Ag5, Ag7, Ag10) are coordinated in a linear manner, while six other $\mathrm{Ag}$ atoms exhibit trigonal planar coordination. Closest Ag...Ag distances are in the range of 2.9353(7) ^ to 3.3260(7) A. Eight of the Ag atoms are connected this way, with a central butterfly-like arrangement and to adjacent $\mathrm{Ag}$...Ag units, while one $\mathrm{Ag} \cdots \mathrm{Ag}$ unit is further apart. The cluster possesses pseudo- $C_{2}$-symmetry. The pseudo- $C_{2}$-axis runs through the centers of the $\mathrm{Ag} \cdot \mathrm{Ag}$ four-ring and the separate $\mathrm{Ag} \cdots \mathrm{Ag}$ dimer. In contrast to known silver sulfide clusters, ${ }^{1 a}$ the cluster does not additionally contain stabilizing phosphine groups attached to the silver atoms. $\mathrm{N} \rightarrow$ Sn coordination of the bidentate organic ligands seems to provide sufficient kinetic stabilization.

The employment of a related gold complex, $\left[\mathrm{Au}\left(\mathrm{PPh}_{3}\right) \mathrm{Cl}\right]$, along with $\left(\mathrm{Me}_{3} \mathrm{Si}\right)_{2} \mathrm{~S}$ in the reaction with $\mathbf{A}$ afforded singlecrystals of the complex $\left[\left\{\mathrm{R}^{1} \mathrm{Sn}(\mu-\mathrm{S})\right\}_{2}\left\{\operatorname{AuPPh}_{3}(\mu-\mathrm{S})\right\}_{2}\right]$ (5). Moreover, addition of hydrazine hydrate to the reaction mixture yielded the hydrazone functionalized derivative $\left[\left\{\mathrm{R}^{3} \mathrm{Sn}(\mu-\mathrm{S})\right\}_{2^{-}}\right.$ $\left.\left\{\mathrm{AuPPh}_{3}(\mu-\mathrm{S})\right\}_{2}\right] \cdot 5 \mathrm{CH}_{2} \mathrm{Cl}_{2}\left(6 \cdot 5 \mathrm{CH}_{2} \mathrm{Cl}_{2}\right)$ (see Fig. 3). In the present case, the derivatization of the organic ligand did not affect the molecular structure of the complex. In 5 and $\mathbf{6}$, a central $\left\{\mathrm{R}^{1,3} \mathrm{Sn}(\mu-\mathrm{S})\right\}_{2}$ unit (cf. ref. 21) is terminated by two $\left\{\mathrm{Au}\left(\mathrm{PPh}_{3}\right)(\mu-\mathrm{S})\right\}$ groups. As in 1-4, 


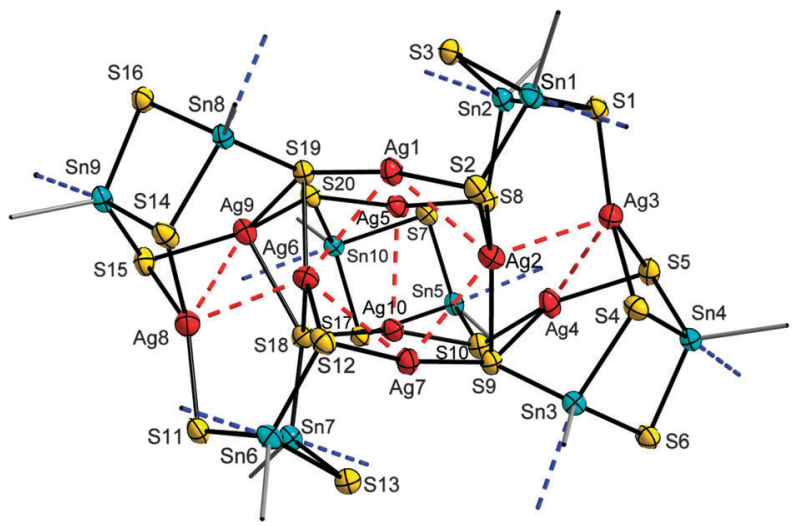

Fig. 2 Molecular structure of the inorganic core of $\mathbf{4}$ along the pseudo$\mathrm{C}_{2}$-axis (ellipsoids drawn at $50 \%$ probability, bonds to organic substituents are indicated by dashed lines). Ag...Ag contacts below $3.4 \AA$ are drawn as dashed red lines. Selected structural parameters $\left[\AA \AA{ }^{\circ}\right]$ : Sn-S 2.3865(16)2.5987(17), Sn-C 2.170(6)-2.187(7), Sn .. N 2.362(5)-2.456(5), Ag-S 2.3666(16)-

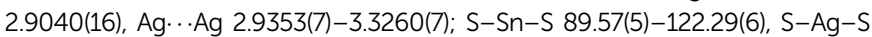
83.47(5)-169.97(6), Sn-S-Sn 85.13(5)-89.69(5), Ag-S-Ag, 72.65(5)-146.30(6), Ag-S-Sn 80.15(5)-144.91(7), C-Sn-N 71.6(2)-75.8(2).

organo-decorated $\mathrm{Sn}$ atoms exhibit a trigonal bipyramidal coordination environment, while all Au atoms show linear coordination. The structural parameters of the central part is similar in both complexes, but the orientation of the attached $\left\{\mathrm{Au}\left(\mathrm{PPh}_{3}\right)(\mu-\mathrm{S})\right\}$ units is different. In 5, they point away from the central $\mathrm{Sn}_{2} \mathrm{~S}_{2}$ ring, with a C1-Sn1-S2-Au1 trans arrangement, whereas in 6, the corresponding atoms show a cis arrangement. While interatomic distances are similar in both complexes, the Sn1-S2-Au1 and S2-Au1-P1 angles show notable differences in both complexes, indicating the influence of the functional group included in the organic ligand.

In summary, a series of ternary group 11 organotin sulfide clusters have been synthesized and structurally characterized. The choice of the very group 11 metal $\mathrm{M}$ - although added as similar complexes $\left[\mathrm{M}\left(\mathrm{PPh}_{3}\right)_{x} \mathrm{Cl}\right](\mathrm{M} / x=\mathrm{Cu} / 3, \mathrm{Ag} / 3, \mathrm{Au} / 1)$ - causes specific coordination environments that affect the molecular structures.
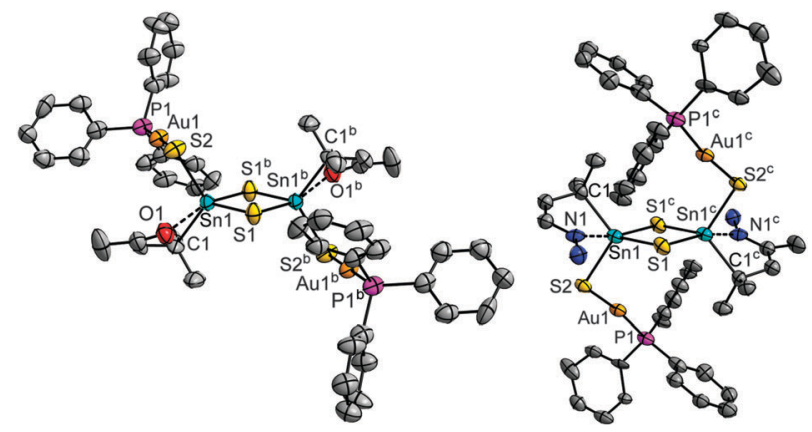

Fig. 3 Molecular structures of 5 (left) and 6 (right) without $\mathrm{H}$ atoms (ellipsoids drawn at 50\% probability). $\mathrm{b}=-x, 2-y, 1-z ; c=2-x, 1-y,-z$. Selected structural parameters $\left[\AA,{ }^{\circ}\right]$ : 5: Sn-S 2.380(2)-2.463(2), Sn1C1 2.189(8), Sn1...O1 2.714(6), Au1-S2 2.291(2), Au1-P1 2.260(2); Sn1S1-Sn1 ${ }^{\mathrm{b}}$ 86.30(7), S1-Sn1-S1 ${ }^{\mathrm{b}}$ 93.70(7), Sn1-S2-Au1 96.63(9), S2-Au1-P1 178.29(9); 6: Sn-S 2.389(3)-2.525(3), Sn1-C1 2.186(14), Sn1 . N1 2.479(11), Au1-S2 2.298(3), Au1-P1 2.250(3); Sn1-S1-Sn1 ${ }^{\mathrm{C}} 89.06(11), \mathrm{S} 1-\mathrm{Sn} 1-\mathrm{S} 1^{\mathrm{C}}$ 90.94(11), Sn1-S2-Au1 103.86(13), S2-Au1-P1 172.84(12).
Accordingly, the products exhibit different compositions and topologies. Unexpectedly, the reaction with the $\mathrm{Cu}$ and $\mathrm{Ag}$ precursor induced in situ reduction of one third of the $\mathrm{Sn}$ atoms under $\mathrm{Sn}-\mathrm{Cu}$ and $\mathrm{Sn}-\mathrm{Ag}$ bond formation. It was shown for the first time that a functionalized ternary $\mathrm{M}-\mathrm{Sn}-\mathrm{S}$ complex could undergo further derivatization.

This work was supported by the Deutsche Forschungsgemeinschaft within the framework of GRK1782.

\section{Notes and references}

$\$$ X-ray crystallographic data: Data collection on a STOE IPDS2 diffractometer using graphite-monochromatized $\mathrm{Mo} \mathrm{K}_{\alpha}$ radiation $(\lambda=0.71073 \AA)$ at $100 \mathrm{~K}$. Structure solution and refinement by direct methods and full matrix least-squares on $F^{2}$, respectively; SHELXTL software. ${ }^{22}$

1 (a) O. Fuhr, S. Dehnen and D. Fenske, Chem. Soc. Rev., 2013, 42, 1871; (b) D. Fenske, T. Langetepe, M. M. Kappes, O. Hampe and P. Weis, Angew. Chem., Int. Ed., 2000, 39, 1857.

2 (a) C. B. Khadka, A. Eichhöfer, F. Weigend and J. F. Corrigan, Inorg. Chem., 2012, 51, 2747; (b) C. Xu, J.-J. Zhang, Q. Chen, T. Duan, W.-H. Leung and Q.-F. Zhang, Inorg. Chem. Commun., 2012, 21, 1; (c) A. Eichhöfer, J. Olkowska-Oetzel, D. Fenske, K. Fink, V. Mereacre, A. K. Powell and G. Buth, Inorg. Chem., 2009, 48, 8977.

3 (a) D. Aldakov, A. Lefrançois and P. Reiss, J. Mater. Chem. C, 2013, 1, 3756; (b) S. Dehnen and M. Melullis, Coord. Chem. Rev., 2007, 251, 1259.

4 (a) C. B. Khadka, B. K. Najafabadi, M. Hesari, M. S. Workentin and J. F. Corrigan, Inorg. Chem., 2013, 52, 6798; (b) W. Yu, O. Fuhr and D. Fenske, J. Cluster Sci., 2012, 23, 753; (c) R. Langer, B. Breitung, L. Wünsche, D. Fenske and O. Fuhr, Z. Anorg. Allg. Chem., 2011, 637, 995.

5 S. V. Kershaw, A. S. Susha and A. L. Rogach, Chem. Soc. Rev., 2013, 42, 3033.

6 A. Proust, B. Matt, R. Villanneau, G. Guillemot, P. Gouzerh and G. Izzet, Chem. Soc. Rev., 2012, 41, 7605.

7 (a) M. Wagner, T. Zoller, W. Hiller, M. H. Prosenc and K. Jurkschat, Chem. Commun., 2013, 49, 8925; (b) M. Bouška, L. Střižík, L. Dostál, A. Růžička, A. Lyčka, L. Beneš, M. Vlček, J. Přikryl, P. Knotek, T. Wágner and R. Jambor, Chem. - Eur. J., 2013, 19, 1877; (c) B. E. K. Barth, B. A. Tkachenko, J. P. Eußner, P. R. Schreiner and S. Dehnen, Organometallics, 2014, 33, 1678.

8 Z. Hassanzadeh Fard, L. Xiong, C. Müller, M. Holynska and S. Dehnen, Chem. - Eur. J., 2009, 15, 6595.

9 M. R. Halvagar, Z. Hassanzadeh Fard, L. Xiong and S. Dehnen, Inorg. Chem., 2009, 48, 7373.

10 M. R. Halvagar, Z. H. Fard and S. Dehnen, Chem. Commun., 2010, 46, 4716.

11 B. E. K. Barth, E. Leusmann, K. Harms and S. Dehnen, Chem. Commun., 2013, 49, 6590.

12 R. Hauser and K. Merzweiler, Z. Anorg. Allg. Chem., 2002, 628, 905.

13 A. Eichhöfer, J. Jiang, S. Lebedkin, D. Fenske, D. G. McDonald, J. F. Corrigan and C. Y. Su, Dalton Trans., 2012, 41, 3321.

14 H. P. Nayek, W. Massa and S. Dehnen, Inorg. Chem., 2008, 47, 9146.

15 J. P. Eußner, B. E. Barth, E. Leusmann, Z. You, N. Rinn and S. Dehnen, Chem. - Eur. J., 2013, 19, 13792.

16 (a) M. Wagner, C. Dietz, S. Krabbe, S. G. Koller, C. Strohmann and K. Jurkschat, Inorg. Chem., 2012, 51, 6851; (b) Tin Chemistry: Fundamentals, Frontiers, and Applications, ed. A. G. Davies, M. Gielen, K. Pannell and E. Tiekink, Wiley, Hoboken, 2008.

17 Another example for the generation of formal $\mathrm{Sn}^{\mathrm{II}}$ during cluster formation from a $\mathrm{Sn}^{\mathrm{IV}}$ precursor was reported in ref. 14 for the compound $\left[\left\{\left(\mathrm{CH}_{2}\right)_{4} \mathrm{Sn}^{\mathrm{IV}}\right\}_{6}\left(\mathrm{CuPPh}_{3}\right)_{6} \mathrm{Sn}^{\mathrm{II}} \mathrm{Cu}_{4} \mathrm{~S}_{12}\right] . \quad\left[\left(\mathrm{C}_{4} \mathrm{H}_{7} \mathrm{~N}_{2} \mathrm{~S}\right)_{6} \mathrm{SnCu}_{4}\right]$ also exhibits $\mathrm{Sn}^{\mathrm{II}}-\mathrm{Cu}$ bonds, see R. E. Allan, A. Bashall, J. S. Palmer, M. McPartlin, M. E. G. Mosquera, J. M. Rawson, A. E. H. Wheatleya and D. S. Wright, Chem. Commun., 1997, 1975.

18 A. E. Reed, R. B. Weinstock and F. Weinhold, J. Phys. Chem., 1985, 83, 735 .

19 (a) TURBOMOLE Version 6.2, (C) TURBOMOLE GmbH 2011. TURBOMOLE is a development of University of Karlsruhe and Forschungszentrum Karlsruhe 1989-2007; Ridft program: (b) K. Eichkorn, 
O. Treutler, H. Öhm, M. Häser and R. Ahlrichs, Chem. Phys. Lett., 1995, 242, 652; (c) K. Eichkorn, F. Weigend, O. Treutler and R. Ahlrichs, Theor. Chem. Acc., 1997, 97, 119; BP86 functional: (d) A. D. Becke, Phys. Rev. A: At., Mol., Opt. Phys., 1988, 38, 3098; (e) S. H. Vosko, L. Wilk and M. Nusair, Can. J. Phys., 1980, 58, 1200; $(f)$ J. P. Perdew, Phys. Rev. B: Condens. Matter Mater. Phys., 1996, 33, 8822; TZVP basis sets: $(g)$ F. Weigend and R. Ahlrichs, Phys. Chem. Chem. Phys., 2005, 7, 3297; (h) F. Weigend, Phys. Chem. Chem. Phys.,
2006, 8, 1057; ECPs: (i) B. Metz, H. Stoll and M. Dolg, J. Chem. Phys., $2000,113,2563$.

20 Z. Hassanzadeh Fard, C. Müller, T. Harmening, R. Pöttgen and S. Dehnen, Angew. Chem., Int. Ed., 2009, 48, 4441.

21 K. Jurkschat, S. van Dreumel, G. Dyson, D. Dakternieks, T. J. Bastow, M. E. Smith and M. Dräger, Polyhedron, 1992, 11, 2747.

22 G. M. Sheldrick, Acta Crystallogr., Sect. A: Found. Crystallogr., 2008, 64, 112. 